\title{
Edward Irving's palaeomagnetic evidence for continental drift (1956)
}

\author{
This paper is dedicated to E. (Ted) Irving: 1927-2014 \\ University of Missouri-Kansas City, USA.E-mail: FrankelH@umkc.edu
}

Edward (Ted) Irving wrote his paper 'Palaeomagnetic and palaeoclimatological aspects of polar wandering' during his first year at the Australian National University (ANU). It was received on 15 February 1956 by the Italian journal Geofisica pura e applicata and published in the following March-April issue (Volume 33). The paper gave new results with strong and novel arguments in favor of continental drift at a time when the fortunes of Wegener's theory were perhaps at their lowest ebb. It contained significant advances and opened up new avenues of research (Frankel, 2012b; Schmidt, 1997).

In the late 1940s and 1950s paleomagnetic work in the UK and the USA followed very different paths. In the USA there was strong, almost universal, disbelief in continental drift; and virtually no support for it among the higher echelons of geology and geophysics (Newman, 1995; Oreskes, 1999; Frankel, 2012a) and paleomagnetic work there reflected these sentiments (Frankel, 2012b). In the UK, opinions were more varied. Harold Jeffreys, then a towering figure in geophysics with a strong following, condemned continental drift. The learned and even-handed geologist Arthur Holmes favored it. The forceful and robust geologist Edward Bailey, Director of the HM Geological Survey, favored it. Rising star Teddy Bullard sat on the fence. Importantly, two senior figures in British science, the physicist Patrick Blackett and geneticist/biologist R. A. Fisher, supported paleomagnetic work on continental drift.

In the UK there was a paleomagnetic research group at the University of Manchester, founded by Blackett which moved to the Physics Department at Imperial College London, and one headed by Keith Runcorn at Cambridge University in the Department of Geodesy and Geophysics. Although owing something to both groups, the sources of Irving's arguments lay in the latter one.

Geomagnetic work started at Cambridge in late 1949 when Jan Hospers arrived from Holland as a research student. He planned to study the magnetization of Icelandic lavas as a stratigraphic tool (Irving, 2011; Frankel, 2012b). Runcorn joined the staff in early 1950 and became Hospers' mentor. From his Iceland collections in the summer of 1950 Hospers found that magnetizations grouped around the direction of the 'geocentric axial dipole' (GAD) or in a direction diametrically opposed-normal and reversed (Hospers 1951). Later collections confirmed that the time-averaged field in Iceland had been that of the GAD (Hospers 1953). This hypothesis was essential to the arguments of the Geofisica article.

Runcorn wanted to study the paleomagnetism of old sedimentary rocks to investigate the secular variation of the field in the remote past. Blackett had developed a very sensitive magnetometer at Manchester that could detect the weak magnetization of sedimentary rocks. The construction of a similar instrument at Cambridge was completed in early 1953 (Creer and Irving, 2012).

In June 1951, Runcorn recruited Ted Irving, a recent Cambridge geology graduate. They collected Precambrian Torridonian Sandstones from northwest Scotland, the study of which became Irving's principal $\mathrm{PhD}$ topic. Irving, who had been taught about continental drift at school and had read Wegener (1924) as an undergraduate, realized that paleomagnetic studies could be used to detect drift. His notebooks (Notebook \#1, 25-29) show that by October 1951 he had understood that the inclination of the geomagnetic field was a function of latitude and if the GAD hypothesis (for which Hospers was just beginning to find evidence) held, then paleomagnetic surveys could provide estimates of former latitudes. Peninsular India had, according to drift theory, undergone the greatest latitude changes and therefore should show this effect most readily. With support from the statistician and biologist Ronald A. Fisher, who had scientific connections in India, Irving requested samples from the Indian Geological Survey. In 1952 (annual report of the Department of Geodesy and Geophysics University of Cambridge 1952-1953) he received an oriented basalt block from each of seven lava-flows spread over 200 miles from the latest Cretaceous-earliest Tertiary Deccan Traps (Irving, 1954, p. 112). The magnetizations were strongly divergent from the present field in India, and showed both normal and reversed magnetizations. He claimed (Irving PhD thesis, 1954, p. 113) that the magnetization directions indicated that "India ha[d] moved from the Southern Hemisphere through $53^{\circ}$ of latitude and has rotated counterclockwise through $28^{\circ}$, a motion required by Wegener." Although not the first to realize that paleomagnetism could provide a quantitative test of continental drift, Irving was the first to act on the idea.

In early 1952, Runcorn recruited Kenneth Creer as a research student. Creer's work yielded pole positions from three Paleozoic formations; and in the later part of 1954 he showed that they fell in time sequence between younger poles from Triassic strata that Clegg and colleagues at Imperial College had studied and older poles identified by Irving from the late Precambrian Torridonian rocks (Creer and Irving, 2012; Frankel, 2012b, pp. 106-116). This became the first paleomagnetic path of polar wander path—essentially Figure 1 of the Geofisica article.

In addition to relative displacement of continents, Wegener (1924), du Toit (1937) and others had invoked the notion of polar wander in the strict sense-i.e. motion of the Earth as a whole relative to its axis of rotation. Thus the pole path-that Creer constructed could reflect 'strict' polar wander (sometimes referred to as 'true' polar wander) and/or the continental drift of Britain. But, as Creer explained, with only one path it was not possible to say how much of it reflected strict polar wander and how much was due to the drift of Britain relative to the substratum (Creer, 1955). For this reason, such paths are now called 'apparent polar wander' (APW) paths. In the 1950s in Cambridge Thomas Gold (1955) developed and spoke publicly about the idea of strict polar wander as a consequence of internal 
redistribution of mass, perhaps related to mantle convection and/or continental drift (Frankel, 2012b, p. 128). Creer's path could in part reflect this.

In his thesis (1954, p. 110) Irving sought unsuccessfully for evidence in support of the latitudes that he had determined from his study of the Torridonian. He wrote:

Clearly it is most desirable to compare the results from the above [paleoclimatic] evidence and from palaeomagnetism. Unfortunately reliable inferences concerning the positions of the geographic poles in Early Paleozoic and Precambrian Times cannot be made, and comparison with the Torridonian results is impossible.

In early 1954 Irving was offered a research fellowship at the new Department of Geophysics at the ANU. In May/June, the Professor of Geophysics there, John Jaeger, visited Irving in Cambridge and they planned a new laboratory to be equipped with a magnetometer of low sensitivity for the examination of igneous rocks, to be built quickly, and one of high sensitivity for examining sedimentary rocks, to be built later. Irving was to send ahead detailed instructions for construction of a new non-magnetic 'hut' on the ANU campus and arrange for materials and instrumental components to be sent to Australia. Jaeger gave a seminar in which he showed that bore-core from the vast Mesozoic dolerite sills of Tasmania were magnetized almost vertically (Jaeger and Joplin, 1955). Irving was listening: that was just what Köppen and Wegener's Mesozoic maps required for southern Australia-high latitude and steep inclination.

Irving left Cambridge in early September to spend a couple of months with his parents in Lancashire and sailed for Australia on 10 November 1954. Creer, now working in London, saw him off on the Tilbury Boat Train. Irving gave him a copy of his $\mathrm{PhD}$ thesis and Creer agreed to send him his thesis when it was completed. After five weeks sailing Irving spent Christmas and New Year with his sister in Sydney-fourteen weeks of complete rest from science. When he arrived in Canberra in the first week of January 1955 Jaeger had seen to it that much had been done. From Irving's drawings, architectural blueprints for the new laboratory had been prepared and many components for the igneous magnetometer were already fabricated. Within weeks Irving had selected a suitably isolated site on the then largely undeveloped ANU campus. The igneous magnetometer was soon commissioned. These were busy days (Frankel, 2012b, pp. 131138).

When Irving arrived in Australia, he planned to sample PermoCarboniferous lavas of eastern New South Wales. As he has explained to me (March 2013 email), "They contained abundant evidence of extensive glaciation and should, on Wegener's Theory, be steeply magnetized. Finding their paleolatitude paleomagnetically would be a direct test of his theory. There were results for comparison from rocks of similar age in the UK. The Australian sequences contained lavas that might be measurable with the igneous magnetometer and results obtained quickly. But Jaeger thought otherwise. He wanted a Land Rover in Tasmania for his summer field season and decreed that I drive it there and, moreover, sample Tasmanian dolerites." But Irving was concerned at the time that they were dated only within wide limits (Jurassic or Cretaceous), and that there were at the time no paleomagnetic results of this age for comparison from elsewhere in the world. Unlike the Late Paleozoic, the Mesozoic of Australia contained evidence of only relatively minor glaciation. Somewhat disgruntled, Irving took the Land Rover to Tasmania in January 1955. Irving returned to ANU from Tasmania in March (Field Notebook \#6) to find in the post Creer's thesis and reprints of the paper Creer $e t$ al. (1954), which had been put together by Creer and Runcorn after Irving had left Cambridge. Both had versions of Creer's APW paths. Irving had been out of touch for over five months and this was the first time he had seen a paleomagnetic APW path.

Creer's thesis path was defined by eight poles, three based on his work, two on work of Hospers, two on Irving's work and one on the work of Clegg and colleagues at Imperial College (Clegg, et al., 1956a, 1956b). Using data in the literature, Irving calculated three more poles, one from the Oligocene of France based on work of Roche (1950) and two from the Carboniferous of the UK from work of Belshé, reported in Runcorn (1955a) All three fell on Creer's path where expected. Creer calculated the pole for the Rose Hill Formation of eastern USA based on data obtained by the US paleomagnetist John Graham (1949) who did not believe in continental drift, and found that it was displaced to the west of his UK path. In Australia, the crucial point was that it was no longer necessary to match poles from Australia with ones of very similar age from Europe. One had the much easier task of matching poles to Europe's long, apparently slow-moving pole-path, as is shown in Figure 1 of the Geofisica article. It was at this point that Irving began to warm to Jaeger's idea of working on the not very accurately dated Tasmanian dolerite.

Irving's notes in his Notebook \#1 (5-23,79) show that he had been familiar since 1951 with the summary in Wegener (1924) of Wegener's paleoclimatic work with Köppen and with du Toit's paleoclimatic arguments favorable to continental drift. He now tackled Köppen and Wegener's larger work Die klimate der geologischen vorzeit (1924). He did not read Geman but a librarian Norma Cook did. The book is well illustrated and he traced into in his notebook the entire sequence of seven paleogeographic maps from Carboniferous to Pliocene and Lower Quaternary ornamented with paleoclimate evidence (Notes, Notebook \#3, pp 101-109, May, 1955). Norma read the captions and the relevant text, mainly a comprehensive review of paleoclimatic indicators, and Irving took notes furiously. Wegener's chapter (1924, Figure 19) gives a plot of latitude of Central Europe through time as determined from paleoclimates. From looking at this and Creer's path it was obvious he could now calulate latitudes of Europe, determined paleomagnetically, and could compare them with Wegener and Koppen's paleoclimate determination, thus comparing results obtained by utterly different methods. What is more, he could see from Wegener's (1924, Figure 17) that in the PermoCarboniferous Europe was on the equator and that the South Pole was near southern Australia, whereas nowadays they are antipodal. That makes no climatic sense unless one assumes drift.

Using the newly completed igneous magnetometer, Irving measured and plotted the magnetization directions of his Tasmanian dolerite samples. He showed his results to Jaeger, who told him to write them up immediately and submit his paper to the Royal Society of Tasmania, which Irving did in June or July 1955.

Runcorn's poles from North America appeared in Nature for 3 September (Day and Runcorn, 1955) and 10 September (Runcorn, 1955a). Travelling by airmail they would have reached the ANU library in mid-September. Irving recalls plotting Runcorn's poles immediately and saw that they all fell to the west of Creer's UK path. So unlike Runcorn (1955a, 1955b), Irving drew two APW paths.

Thus by the end of September Irving had all he needed for his eventual Geofisica article. There was Creer's APW path for Britain. 
He knew enough about past climates to defend the GAD hypothesis and to conduct his indirect proof of continental drift (described below). He had observed the first poles from two Gondwana continents (India and Tasmania), and he had drawn separate pole paths for North America and Europe.

However, Irving initially submitted his paper to the Journal of the Geological Society of Australia. It was rejected. So he went to Jaeger, who advised sending it to Geofisica pura e applicata because he would support it as a member of the editorial board. The paper was received in Milan on 15 February 1956 and published in the March/April issue.

The Geofisica paper gives an account of how "ancient pole positions" and their errors can be calculated from paleomagnetic observations. It lists the 27 poles available at that time: 16 from Europe, 9 from North America, one each from India and Australia. All were based on natural remanent magnetization without demagnetization but Irving used only results that field tests showed or implied stability. If continents had remained fixed the same polepath should be obtained from all continents but the Geofisica paper showed that this was not true: Europe and North America had different paths and the poles from the Deccan Traps and the Tasmanian dolerites fall nowhere near either the European or the American paths. Irving reasoned that if the rotation and time-averaged magnetic field had always coincided (i.e. if the GAD hypothesis held) and if climate had been largely a function of latitude, then the paleoclimate determined from geological evidence should be broadly consistent with latitudes determined paleomagnetically from the same region. He showed that in general that was so (Figure 3); with this supporting evidence he extended the GAD model through the Phanerozoic.

Finally, Irving introduced an ingenious indirect argument in support of continental drift. Assuming continents to be fixed, he showed that such an assumption leads to a contradictiondemonstrating that continental drift did occur if the other premises are true. Having shown that the paleomagnetic and paleoclimatic evidence from the same continent were in accordance with one another (Figure 3), he recognized that if continents had remained fixed he could, from one polar-wander path from one continent, calculate the latitude variations for any other continent; and such variations should be consistent with paleoclimatic evidence everywhere. But this was not the case (Figure 4). One of the most glaring inconsistencies was that the paleomagnetic evidence from the UK indicated that eastern Australia was in low latitudes during the Permian, at which time it was in fact known to have been repeatedly glaciated (Figure 4, III). Hence the paleomagnetic and paleoclimatic data made no sense unless continental drift was invoked.

Irving did recognize uncertainties and anomalies. When calculating the confidence limit for the Tasmanian pole, Irving (1956a) had used Creer's (1955) formula, which did not allow for the latitude effect on declination error. Irving realized this (Notes, Notebook \#11, 76-79) only after he had returned the proofs (Irving, 1956a) but corrected it before he submitted Geofisica in February 1956. He recalculated all pole errors. He also recognized a notable anomalythe disagreement between the supposedly Carboniferous Squantum Tillite of the Boston area at a time for which the paleomagnetic data indicated equatorial latitudes (Figure 3, II). This problem was not resolved at the time, but a half-century later it was no longer an anomaly because the tillite is considered to be Vendian in age (late Precambrian).

Exactly when Irving submitted his intended paper to the
Geological Society of Australia and what it contained is not certain. It could have been about August 1955, with only the European APW path; or after September with paths for both Europe and North America. He had time for either. The Geofisica paper is strangely titled: 'Paleomagnetic and paleoclimatological aspects of polar wandering'. It is strange because Irving gave strong evidence for continental drift without even mentioning it, but said nothing substantive about strict polar wander. I favor the earlier initial submission date because the title would be somewhat less surprising than it would be for a paper with one path. The term 'continental drift' was absent not only from the Geofisica paper but also from the Tasmania dolerite paper (1956a). Mindful of the prejudice of the times Irving likely considered 'continental drift' to be a potentially 'toxic' term.

In explaining the differences between the APW paths for Europe and North America and between them and the poles from Tasmania and India, did Irving believe that both strict polar wandering and continental drift had occurred or was he speaking only of apparent polar wandering and that only continental drift had occurred? I think he was claiming that both did; and in this he was wrong. Logically he should have concluded that continental drift had occurred, which might or might not have been accompanied by strict polar wander.

Although the recognition that Europe and North America had separate polar-wander paths was the first notable step made in support of continental drift, Irving's paper has rarely been acknowledged for this finding. Either Runcorn (1956a) or (1956b) are almost always credited. None of the papers appeared in mainline journals. I have documented in detail how Runcorn came to draw the two separate paths and accept continental drift in about July 1956, which was "about six months after he took up his new post at Newcastle upon Tyne ... in Jan 1956" (Frankel, 2012b: 155, 162). That was at least four months after the acceptance of the Geofisica paper and two months after its publication. Runcorn (1956a) was published in November 1956, over six months after the Geofisica paper. Runcorn (1956b) was submitted after Runcorn (1956a) appeared in August 1956, four months after publication of the Geofisica paper. Elsewhere (Frankel, 2012b: 172190) I have shown that: (1) during the critical period between the acceptance of the Geofisica paper in February and Runcorn's acceptance of continental drift about July 1956, Runcorn was under considerable pressure by colleagues in Newcastle to accept continental drift; (2) that he had become aware of work by Imperial College in Clegg et al. (1956), which confirmed Irving's Deccan Trap result with much added detail; and (3) that there is in Runcorn's archive a late draft of the Geofisica paper sent to him by Irving. So he very likely knew of Irving's work in early 1956. Runcorn had ample reason to change his mind.

Alan Cox, one of the early important paleomagnetists from North America certainly did not fully appreciate the Geofisica paper in his influential review (Cox and Doell, 1960). It was only almost two decades later, in his succinct and gracious citation for Irving's 1979 Walter Bucher Medal, that he fully recognized the importance of the Geofisica article.

In a seminal 1956 paper, Irving determined the paleolatitudes of North America, Europe, and Australia from paleomagnetic data and compared these with the geological records on these continents of paleoclimates. He demonstrated that, except possibly for the Precambrian, the two data sets were in remarkably good agreement: coral reefs and rocks 
formed in ancient deserts lay at low paleomagnetic latitudes whereas ancient glacial deposits lay at high paleomagnetic latitudes. Using paleomagnetic data, Irving calculated pole paths for North America and Europe and noted that the path for North America lay to the west of the path for Europe. He concluded in his 1956 paper that during the Mesozoic and Paleozoic North America lay closer to Europe and that India, Australia, North America, and Europe had all undergone continental drift (Cox, 1979, p. 659).

Irving's 'Italian' paper was, I believe, a 'classic' contribution to the development of geology, yet it is still rather little known. It is, therefore, highly appropriate that it should be republished here.

\section{Acknowledgements}

Irving's paper, which appeared in Geofisica pura e applicata (1956), is reprinted with permission from Springer Basel. Geofisica pura e applicata continues to be published by Springer Publishing with the English title equivalent Pure and Applied Geophysics. This introduction to Irving's landmark 1956 Geofiscia paper could not have been done without extensive discussion and help from Ted Irving. Although I discussed the importance and findings of Irving's paper in the second volume of my account of the controversy over continental drift (Frankel, 2012b), I did not describe the development of Irving's ideas that led to his writing of the paper. Irving kindly explained how, when, and why he wrote the paper. He also examined his working notebooks to check and confirm his memories, and even provided me with relevant passages. I also acknowledge David Oldroyd's importance for this project. Without him, this introduction would not exist. He came up with the idea of republishing Irving's paper, prepared the paper for republication, and kept after me to complete the introduction.

\section{References}

Clegg, J. A., Almond, Mary, and Stubbs, P. H. S. 1954a. The remanent magnetization of some sedimentary rocks in Britain. Philosophical Magazine, v. 45, pp. 583-598.

Clegg, J. A., Almond, Mary, and Stubbs, P. H. S. 1954b. Some recent studies of the pre-history of the Earth's magnetic field. Journal of Geomagnetism and Geoelectricity, v. 6: pp. 194-199.

Clegg, J. A., Deutsch, E. R. and Griffiths, D. H. 1956. Rock magnetism in India. Philosophical Magazine, v. 1: pp. 419-431.

Creer, K. M. 1955. A preliminary palaeomagnetic survey of certain rocks in England and Wales. PhD Dissertation: Cambridge University.

Creer, K. M. and Irving, E. 2012. Testing continental drift: constructing the first palaeomagnetic path of polar wander (1954). Earth Science History, v. 31, pp. 111-145

Creer, K. M., Irving, E. and Runcorn, S. K. 1954. The direction of the geomagnetic field in remote epochs in Great Britain. Journal of Geomagnetism and Geoelectricity, v. 6, pp. 163-168.
Creer, K. M., Irving, E. and 1957. Geophysical interpretation of palaeomagnetic directions from Great Britain. Philosophical Transactions of the Royal Society of London, v. A250, pp. 144-155.

Day, A. A. and Runcorn, S. K. 1955. Polar wandering: some geological, dynamical and palaeomagnetic aspects. Nature, v. 176, pp. 422-426.

Frankel, H. 2012a The Continental Drift Controversy, Volume I: Wegener and the Early Debate. Cambridge: Cambridge University Press.

Frankel, H. 2012b. The Continental Drift Controversy, Volume II: Paleomagnetism and Continental Drift. Cambridge : Cambridge University Press.

Graham, John W. 1949. The stability and significance of magnetism in sedimentary rocks. Journal of Geophysical Research, v. 54: pp. 131-167.

Gold, T. 1955. Instability of the Earth's axis of rotation. Nature, v. 175, pp. $526-529$.

Hospers, J. 1951. Remanent magnetism of rocks and the history of the geomagnetic field. Nature, v. 168, pp. 1111-1112.

Hospers, J. 1953. Reversals of the main geomagnetic field, Part I. Proceedings of the Royal Netherlands Academy of Sciences, Series B, v. 56, pp. 467476.

Irving, E. 1954. The palaeomagnetism of the Torridonian sandstone series of North-Western Scotland. PhD dissertation (unpublished). University of Cambridge, Cambridge.

Irving, E. 1956a. The magnetisation of the Mesozoic dolerites of Tasmania. Papers and Proceedings of the Royal Society of Tasmania, v. 90: pp. $157-168$.

Irving, E. 1956b. Palaeomagnetic and palaeoclimatological aspects of polar wandering. Geofisica pura e applicata, v. 33: pp. 23-48.

Irving, E. 2011. Jan Hospers' key contributions to geomagnetism. EOS, v. 89 : pp. $457-458$

Jaeger, J. C. and Joplin, Germaine A. 1955. Rock magnetism and the differentiation of dolerite sill. Journal of the Geological Society of Australia, v. 2: pp. 1-19.

Köppen, W. and Wegener. A. 1924. Die Klimate der geologischen Vorzeit. Berlin: Verlag von Gebrüder Borntraeger.

Newman, Robert, P. 1995. American intransigence: the rejection of continental drift in the great debates of the 1920s. Earth Sciiences History, v. 14, pp. 62-83.

Oreskes, Naomi. 1999. The Rejection of Continental Drift. New York: Oxford University Press.

Roche, A. 1950. Sur les caractères magnétiques du système éruptif de Gergovie. Comptes rendus de l'Académie des Sciences Paris, v. 230 (1951), pp. 113-115.

Runcorn, S. K. 1955a. Palaeomagnetism of sediments from the Colorado Plateau. Nature, v. 176, pp. 505-506.

Runcorn, S. K. 1955b Palaeomagnetism of sediments from the Colorado Plateau. Rock magnetism-geophysical aspects. Advances in Physics, v. 4, pp. 244-291.

Runcorn, S. K. 1956a. Palaeomagnetic comparisons between Europe and North America. Proceedings of the Geologists' Association of Canada, v. 8 , pp. $77-85$.

Runcorn, S. K. 1956b. Paleomagnetism, polar wandering and continental drift. Geologie en Mijnbouw, v. 18, pp. 253-258.

Schmidt, P. W., 1997. The sesquicentennial of paleomagnetism and rock magnetism in Australia. AGSO, Journal of Australian Geology and Geophysics, v. 17, pp. 137-143.

Wegener, Alfred. 1924. Die entstehung der kontinente und ozeane. Braunschweig: Friedrich Vieweg \& Sohns, $4^{\text {th }}$ edn. 